\title{
Formation of Analytical Tools of Anti-Crisis Business Regulation on the Basis of Logit-Models
}

\author{
A.N. Opekunov ${ }^{1}, I . N$. Kamardin $^{1}, N . V$. Nikitina $^{2, *}$ and N.V. Kamardina ${ }^{1}$ \\ *Corresponding author: nikitina_nv@mail.ru \\ ${ }^{1}$ Penza State University, Penza, Russia \\ ${ }^{2}$ Samara State University of Economics, Samara, Russia
}

\begin{abstract}
Current trends in economic development emphasize the importance of crisis management at both the macro and microeconomic levels. The analysis of current problems of Russian enterprises has shown that at present some outdated approaches to this problem prevail in domestic science and practice. Therefore, a new scientific direction "Anti-crisis business regulation" is becoming increasingly important. In the world practice, the term crisis-management is not associated solely with the problems of bankruptcy. On the contrary, it is a broader concept that includes a range of problems. Therefore, the technology of anti-crisis business regulation should be universal enough and allow to solve any socioeconomic, financial and organizational problem.

The basic tool of anti-crisis business regulation are methods of diagnostics, monitoring and forecasting of the crisis phenomena at the enterprises which have, first of all, preventive character. One of such approaches is a method of forecasting the probability of insolvency (bankruptcy) on the basis of logitmodel. This approach, tested on the sample of enterprises of Penza region, has shown a significant increase in the accuracy of forecasts compared to traditional models, for example: Altman and others.
\end{abstract}

Keywords: Anti-crisis management, anti-crisis business regulation, business model, business analysis, bankruptcy of the organization.

\section{Introduction}

Instability and uncertainty of the economic situation in the country where the organizations operate predetermine their exposure to financial risks. Clearly, the main risk for the organization has been and remains the risk of financial insolvency.

However, it is necessary to note the insufficiency of measures on state regulation of crisis phenomena specifically at the microeconomic level. In Russia, responsibility in this area is delegated to the Federal Tax Service as a non-main activity and is reduced to generating bankruptcy statistics. Some aspects of anti-crisis management of organizations of the real sector of the economy are reflected in publications and practical studies of scientific institutions.

\section{Problem Statement}

Modern trends in the development of both the global and domestic economies form special requirements for crisis management. As noted by many authors, the main feature of this process is the transformation of crisis management into a crisis management business regulation [1].

The main tools of anti-crisis business regulation are analytical functions of monitoring and diagnostics. In turn, diagnosis changes its target function from the assessment of the financial condition of the enterprise to the assessment of the sustainability of the enterprise and business. Analytical methods have a preventive character, the purpose of which is the timely identification of existing and potential risks of the enterprise, the recognition of the probability and causes of the crisis, as well as the possibility of increasing competitive advantages and financial recovery.

\section{Research Questions}

Theoretical aspects of crisis management are considered in the works of A.V. Azizov \& D.S. Ramazanovna [2], N.T. Hill, S.E. Perry \& S. Andes [3]. The issues of forming the methodology of anti-crisis business regulation are disclosed in the publications of A.N.Ryakhovskaya, \& S.E. Kovan [1], D.O. Konovalova [4], A.V. Filushina [5] and other authors.

E. Altman \& E. Hotchkiss, G.D. Bordeianu, R. Florin, M.D. Paraschivescu \& W. Pâvâloaia, D.J. Lacombe \& S.G. McIntyre, L.Mandru, A. Khashman \& C. Carstea and other authors are devoted to research and development of discriminant methods and models of bankruptcy forecasting: [6-11].

Models of forecasting insolvency (bankruptcy) at enterprises has shown a number of their shortcomings. They include low adaptability of these models to the Russian practice, the probability of obtaining ambiguous results with a 
low degree of accuracy of the forecast. The principles of formation and justification of application of logit-models for forecasting the probability of insolvency (bankruptcy) of enterprises are considered in the works of G.A. Khaidarshina [12] and S.A. Gorbatkov [10].

\section{Purpose of the Study}

In order to identify and predict the insolvency (bankruptcy) of enterprises, science and practice offer many methods and indicators. However, the choice and justification of the accuracy of these methods remains an under-disclosed and understudied task. The development of business analysis tools necessitates additional research into their application in crisis management, which has become the main goal of the study.

\section{Research Methods}

In the world practice there are a number of traditional methods of assessing the probability of bankruptcy of enterprises. In our opinion, several basic approaches should be distinguished:

- discriminant analysis is presented by the models of E.Altman \& E.Hotchkiss [6], G.D. Bordeianu, R.Florin, M.D. Paraschivescu \&W.Pâvâloaia [7];

- multivariate rating analysis, represented by the models, IGEA model [11];

- calculation of the bankruptcy forecast coefficient is presented by the models of I.G. Kukukina [11];

- modeling with the help of the apparatus of fuzzy sets, etc. [5].

However, in recent years, foreign practices in the field of assessment of bankruptcy of organizations have almost completely abandoned the use of models based on discriminant analysis, as these models often give ambiguous estimates. Besides, it is necessary to note their limitation in the field of inclusion of qualitative factors, which does not allow assessing the impact of external and internal environment factors on the business processes of the organization in a comprehensive manner.

In our opinion, one of the first elements of the toolkit of business analysis in the practice of crisis management should be more accurate logit-models [12].

\section{Findings}

\subsection{Results}

Unlike discriminant models, logit-models allow not only to draw a conclusion concerning belonging of the enterprise to the group of potential bankrupt entities, but also to estimate the risk of bankruptcy of the enterprise on a quantitative scale.

In logit-models there are no problems with unambiguous interpretation of the resulting indicator $(\mathrm{P})$, which can take values only in the range from 0 to 1 and determines the nominal value of the probability of bankruptcy [12].

In each logit-model, the probability of bankruptcy is calculated using the general formula of the logistic function, which looks like below:

$\mathrm{P}=1 /\left(1+\mathrm{e}^{\wedge} \mathrm{y}\right)(1)$

where $\mathrm{P}$ is the probability of bankruptcy in fractions of one unit (taking on values from 0 to 1 );

e - basis of natural logarithm (Euler constant equal to 2.71828);

Y - coefficient - integral index calculated depending on the developed model [1].

The first domestic economists to offer their own logit-model for predicting the probability of bankruptcy were M.V. Evstropov and G.A. Khaidarshina.

In order to differentiate organizations based on the results of calculation of the obtained models, 5 risk categories have been defined. This division has a "step" of $20 \%$ and allows to refer the organization to one or another risk category.

$0.8<\mathrm{CBR}<1$ - Maximum risk of bankruptcy.

$0.6<\mathrm{CBR}<=0.8$ - High risk of bankruptcy.

$0.4<\mathrm{CBR}<=0.6$ - Average risk of bankruptcy.

$0.2<\mathrm{CBR}<=0.4$ - Low bankruptcy risk.

$0<\mathrm{CBR}<=0.2-$ Minimum risk of bankruptcy [12].

\subsection{Approbation}

According to the data of the Unified Federal Register of Bankruptcy Information, in 2016 the number of legal entities in the Penza Region was 58, which is almost 40\% less than in 2015 - 96 entities. 
If we look at the bankruptcy structure of organisations in the Penza Region in 2016 based on the type of economic activity, we can identify four industries in which the largest number of legal entities - bankrupt entities - were concentrated.

Construction (25\%), agriculture (15\%), real estate transactions (10\%) and other services (7\%) account for 57\% of the total number of legal entities that went bankrupt. The remaining $43 \%$ are in other types of activities.

The ranking of bankrupt organizations by type of economic activity shows that the growth rate in most industries has been decreasing significantly.

For real estate operations, the growth rate has decreased by $85.2 \%$ as compared to the previous year; for wholesale trade - by $80.0 \%$; for production, transmission and distribution of electricity, gas, steam and hot water - by 66.7 ; for production of other non-metallic mineral products - by $60.0 \%$; for production of machinery and equipment, and for retail trade - by $50.0 \%$; for construction and agriculture - by $33.3 \%$.

We can also say that the ranking, which was conducted for the bancrupt organizations of the Penza region in terms of the structure of economic activities almost coincides with the structure, which was selected for the bankruptcy in Russia. In other words, the sectors of economic activity that are most susceptible to bankruptcy in Russia coincide with the Penza region.

Therefore, the proposed model for assessing the probability of insolvency (bankruptcy) was tested on the example of a sample of enterprises of the Penza region (15 enterprises of different industries) that applied the bankruptcy procedure in 2016. The assessment of bankruptcy risk based on the results of CBR values was carried out for the period from 2014 to 2016 , i.e. for the three years preceding the bankruptcy.

The accuracy of bankruptcy risk assessment using the proposed model was $92 \%$ for the forecast period of 1 year. Comparative assessment of the reliability of bankruptcy models is presented in the table below.

Table 1. Degree of reliability of bankruptcy models

\begin{tabular}{|l|c|c|c|l|}
\hline \multicolumn{1}{|c|}{ Model } & $\begin{array}{c}\text { Probability up to } \\
\text { 1 year, \% }\end{array}$ & $\begin{array}{c}\text { Probability up } \\
\text { to 2 years, } \%\end{array}$ & $\begin{array}{c}\text { Probability after } \\
\text { 2 years, } \%\end{array}$ & \multicolumn{1}{c|}{ Note } \\
\hline $\begin{array}{l}\text { Altman's } \\
\text { two-factor }\end{array}$ & 65 & 60 & 74 & $\begin{array}{l}\text { Variety of financial } \\
\text { processes is not always } \\
\text { reflected in solvency } \\
\text { ratios }\end{array}$ \\
\hline $\begin{array}{l}\text { The original } \\
\text { Altman's } \\
\text { five-factor }\end{array}$ & 85 & 51 & 37 & $\begin{array}{l}\text { Lack of information on } \\
\text { the market value of the } \\
\text { company's capital }\end{array}$ \\
\hline $\begin{array}{l}\text { Advanced } \\
\text { five-factor }\end{array}$ & 88 & 66 & 29 & $\begin{array}{l}\text { Adapted to Russian } \\
\text { reporting (accounting) }\end{array}$ \\
\hline Logit-model & 92 & 86 & 71 & $\begin{array}{l}\text { Identified on the basis } \\
\text { of the assessment of } \\
\text { Russian companies, } \\
\text { taking into account the } \\
\text { macroeconomic } \\
\text { situation, industrial } \\
\text { affiliation of the } \\
\text { company }\end{array}$ \\
\hline
\end{tabular}

Source: compiled by the authors based on [11]

\section{Conclusion}

Thus, today the anti-crisis business regulation at the micro level becomes an urgent topic for any enterprise, as one of its main tasks is to ensure stable functioning and development of the company, prevention and forecasting of crisis phenomena.

In the structure of anti-crisis business regulation the first place is being taken by the issues of business architecture, business modeling and business analysis. Traditional methods of diagnostics of a financial condition of the enterprise in the course of anti-crisis business regulation are used as measures of restoration of solvency.

Anti-crisis business regulation seems to be quite an effective method, which plays a significant role in the timely identification of current and potential risks, the choice of necessary measures to manage the organization.

\section{References}

1. A.N. Ryakhovskaya, S.E. Kovan, Anti-crisis management: a modern concept and the main instrumentarium. Managerial Science, 5(3), 45-55. DOI: 10.26794/2304-022X-2015--3-45-55 (2015).

2. A.V. Azizov, D.S. Ramazanovna, A brief analysis of the dynamics of bankruptcies in the Russian Federation, individual regions and forms of business. NOVAINFO, 1(45). 74-82 [in Rus.] (2016). 
3. N.T. Hill, S.E. Perry, S. Andes, Evaluating firms in financial distress: An event history analysis. Journal of Applied Business Research (JABR), 12(3). 60-71. DOI: 10.19030/jabr.v12i3.5804 (2011).

4. D.O. Konovalova, Improving the financial sustainability of enterprises as a direction of crisis management. $\mathrm{PhD}$ dissertation. Moscow: AHO HPE "Russian Academy of entrepreneurship» [in Rus.] (2015).

5. A.V. Filyushina, Innovative tools of crisis management. Innovation Management, 4, 71-81 [in Rus.] (2015).

6. E. Altman, E. Hotchkiss, Corporate financial distress and bankruptcy: Predict and avoid bankruptcy, analyze and invest in distressed debt, 3rd Edition. New York, NY: John Wiley and Sons, Ltd (2005).

7. G.D. Bordeianu, R. Florin, M.D. Paraschivescu, W. Pâvâloaia, Analysis models of the bankruptcy risk. Economy Transdisciplinarity Cognition, XIV(1), 248-259 (2011).

8. D.J. Lacombe, S.G. McIntyre, Hierarchical spatial econometric models in regional science. Regional Research Frontiers, Advances in Spatial Science: The Regional Science Series, 2, 151-167. DOI: 10.1007/978-3-319-50590-9 (2017).

9. L. Mandru, A. Khashman, C. Carstea, The diagnosis of bankruptcy risk using score function. In L.A. Zadeh, J. Kacprzyk, N. Mastorakis, et al. (Eds.), Proceeding of the 9th WSEAS international conference on artificial intelligence, knowledge engineering and data base (pp.83-88). Cambridge, UK: University of Cambridge (2010).

10. S.A. Gorbatkov, S.A. Farkhieva, Sensitivity of a neural network dynamic method for evaluating bankruptcies in management models for restructuring a corporation's credit debt. Naukovedenie, 8(2). 1-20. DOI: $10.15862 / 67 T V N 216$ [in Rus.] (2016).

11. I.G. Kukukina, Accounting and analysis of bankruptcies. Moscow, Russia: Finance and Statistics [in Rus.] (2014).

12. G.A. Khaidarshina, Methods for assessing the risk of bankruptcy of an enterprise. Extended abstract of $\mathrm{PhD}$ dissertation. Moscow: Financial Academy under the Government of the Russian Federation [in Rus.] (2009). 